なる㴽か, 特別の差を認めなかったが, 全般的に外䂓性の 個人の不注意に上る学災が全疾患の90\%前後をしめ, そ の荻害発生は安全保安運動の推進により予放できること が認められた。九州・山口地区に和ける労災疾病発生率は 1 号学災 $(0.98 \%$ \% ， 3 号 $(0.50 \%) ， 2$ 号 $(0.44 \%$ \% ， 6 号롤 $(0.25 \%) ， 14 \sim 32$ 号各種”中毒群 $(0.11 \% 0), 38$ 号 $(0.08 \% 0) ， 5$ 号， 7 号 $(0.05 \% 0) ， 12$ 号 $(0.01 \%$ )であっ た。

以上，九州・山口地区に就学笔発生に関しては，山 口を含めた福阔，佐賀，長崎，熊本各県の北部ブロック 之, 大分, 宮崎, 庇児島の南部ブロックに拈いて, 前者 は学猋発生率も高率であり，その発生学炭疾病の内容も 多種多様であるのに比較して，後者は学多発生率も低率 であり，その発生労災疾病の内容は単純であることが観 察され，第 2 次産業と第 1 次産業の発澾の差に上り，烦 害の発生率内容が異なることが明らかに覞察できた。し かしその災害発生率は外傷性の疾病が主体をしめること より考光るとき，今後とも保安運動の推進が必要である ことを痛感した。

\section{9. 某機械工業における労災上の骨折}

$$
\text { 秋山舜一，福山裕三（不二越病院） }
$$

企業が掂大されるにつれて，外僬性の災憲は増加の途 をたどるが，その外㑺性災害の発生状沉の概峈を見よう とするとき，ある種の機械工業では骨折がその指標とな り得る。

即らこの種の工業で使われる機械及び材料はその災害 が甚しい時は骨折に至らしめる伦険性を充分に具倩して いるからである。

このような観点から私達は不二戎鋼材富山工場及びそ の下請会社に括ける昭和34年 1 月以後現在に至るまでの 労荻上の骨折の発生状況を統計的に解析したのでここ に報告する。要旨はつぎのとおりである。

1）この種の工業に括る骨折の 93\% \%でが指趾に 発生し，指趾ともに左右の差はなく，示指，中指，拇趾 に最も多く発生している。前二者はこれらの指が作業の 中心となること，後者は体の支点となることに関連があ ろら。

2）骨折の原因では材料の落下が多く，ついでプレス による压挫，砥石による切削の順となっている。

3) 骨折の発生時刻は作業終了面前即ち午前11時，午 後 3〜4 時に最も多く発生している。

4） 1 週の中では月，土矅に多く，肉体的疫学上りも 精神的要素に深い関係を有すると思われる。
5）季節的には入社時の 4〜5 月ごろと 10〜12月の寒 冷時に多く発生している。

6) 年齢別に見ると，15－20藏の未熟者群と40歳前後 の高命者群に多い。

7）経験年数別に見ると，5年内外のようやく機椷に

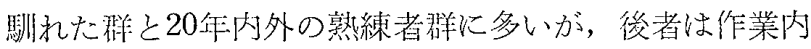
容の複雑さ（段取り）と高令による骨変化がその要因を なしているものと舁われる。

\section{0. 林業作業による災害の調疽研究}

柳沢文徳（東医菌大農研）

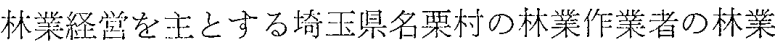
に関連して，発生した災害の淍查研究成績を報告する。

昭和31年度の同村の受診篗病洞查上り，国際㙏病分類 による 3 XVI 項の発生率は人口1,000に対しで 97.6で

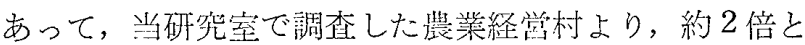
いら実態であることより，林業村では外傢がいかに多い かが判明した。

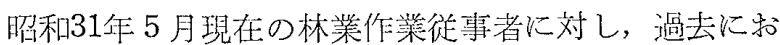
げる林紫災害の状海を検詩した。その災害の程度は約 1

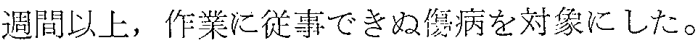

災害者は 117 名で，受傷回数は 148 回で 1 回，82.9\% 2 回 10.3\%，3回 $5.1 \%$ で最高が 5 回であった。

年齢別で清青壮年厤に多く認められた。傷病区分では 打撲傷 $30.4 \%$ ，骨折 $40.5 \%$ ，切傷 $17.6 \%$ ，刺傷 $2.7 \%$ 挫傢 $6.1 \%$ ，その他 $2.7 \%$ であった。骨折が多いのに 注目さ机る。ぬた長期にわたる後遗症が認わら机たもの は約 50\%であった。

作業内容との関係は村木運搬が 64 回，つぎが伐木で 16回，枝打13回となっており，運搬でも“そり引き”の 場合が王倒的に多いのは注目される。

その弫か集萝した資料より解析しえた成績を二，三の ベるが，本調查によって，林業作㮍による多害は大さな 賃病が多いことにより，作盖内容の改善の必要性がつよ く認められた。

\section{1. 救急用人工呼吸装置の試作について}

梨本一郎，山口 裕（東医崡大衛生）

座策部門に招ける救急用人工呼吸装犆は多種にわたっ ているが，機能的には满足すべきのがきわめて少な い。演者らは，従来指摘されている不備な点を改良して 新らしい機情の人工呼吸装犆を試作し，実験的仔成績 を得た。 
機構的には，送気にはつねに新鮮な空気を用い，また 脑コンプライアンスを吸引によって補助する上らにし， これらの動作を 1 行程の手動操作でできるよらたした。 また，送気压は $15 \sim 20 \mathrm{cmH}_{2} \mathrm{O}$ ，吸引压は $-5 \mathrm{cmH}_{2} \mathrm{O}$ 以 下に保つよらにした。さらに，送気には必要に応じて， デマンド・バルブを借光た酸素もしくは圧維新鮮空気の 供給装置を附属し，高気圧作業環境，有書ガス発生事收 現場などにおける救急用にも使用できるようにした。

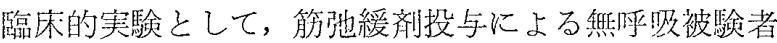
に本装置を用い，血中 $\mathrm{O}_{2}$ 並びに $\mathrm{CO}_{2}$ 量の変化を又た が，正常呼吸時と比較して，墂とんど差を認めなかっ た。

\section{T.レーヨン工場に於ける業務上災害の統計的観察} （第 1 報）

$$
\text { 宮川一夫（東邦レーヨン徳島工場） }
$$

各産業部門に拈ける業務上经害を分析調查することは 安全思想の普及と災害対策の樹立に必要である。某スフ 製造業ならびにスフ紡續菜工場における最近 5 力年間の 業務上の災害を統計的に能察し，つぎの如き結果を得た ので，その大要を報告し，御批判を仰ぐ次第である。

1. 多害登生率

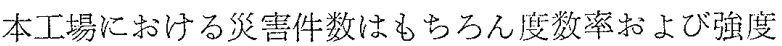
率も年とともに逐次減少している。しかし休業日数は減 少の傾向にあるが，損失日数はむしろ增加の傾问を示し ている。これは機能障害を残す如さ荻羖が跡をたたない ためでないかと考光ら机る。

2. 年間に扣ける倠害発生状沉

他座業に扣けると同様に贸害の発生は春より夏にかけ て多く, ことに $3,5,7$ の隔月に多発し, 秋から冬に かけて減少している。

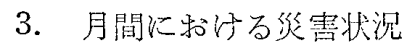

月間には活济 1 週間の間榢を持った二つの $3 \sim 4 \%$ の 発生率を示寸山と， $2 \%$ 内外を示蛮二つの谷が交互に連 続したような一のの曲線が想定される。

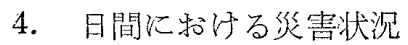

午前中は始業後 1 2 時間ごろに $12 \%$ ，午後は昼食後 1〜2 時間ごろに 11\% の災憲発生を見ている。

5. 勤続年数と苂害頻度との関係

勤続 1〜2 年で 16.5\%，6力月までが 10.3\%，4〜5 年で $10.2 \%$, 勤続 8 年以上は非常に減少している。

6. 傷慧の種類

挫創，切創，骨折の順で化纎工場に特有な前眼炎，ガ ス中毒の発生はごくまれである。
7. 傷害の部位

四肢の傷書が $3 / 4$ を占め，指部 $28.2 \%$ ，足部 $10.7 \%$ 手部 $10.3 \%$ ，趾部 $7.7 \%$ で指部，趾部に拈いては右側 の傷害が多い。

\section{〔労 働 生 理〕}

\section{3. 生体諸袎能の年令变化 第 1 啹 Step test(橋本) による代謝循䘫機能と体力評点}

白石信海, 浅野和男, 平良真豊, 飯泉清一郎

阔常直，中村立 (日大衛生)

橋本邦衛

(国鉄労研)

17 才から 70 才交での各年令犀の健康男子41 名につい $\tau$ ，橋本の Ttep test (台高 $30 \mathrm{~cm}$, 每分 tempo 30回 持続時:間 2 分間, 運動後 3 分間立位安静保持）を年令, 体重にかかわりなく同一条件で行ない，つぎの結果を得 た。

1. 着衣体塞当り酸素需要量拉よび酸素債は20才台が 最も小さく，年命とともに漸次嬶大する。機械效率は年 令とともに劣化する。

2. $\mathrm{R} / \mathrm{E}$ 比（運動時 2 分間の代謝量に対する回復時 3 分間の代謝増の比)， $\mathrm{RQ}, \mathrm{CO}_{2}$ 超過排出量も20才台を最 低として年令ととも火溯大するが，換気当量は30～35才 が最も良く，その前後の年命では增大走した。

3. 運動前の安静時心捇数は年令とあまり関係を示さ ないが，運動時（運動終末30秒間の平均值）ならびに回 復時（運動終了後 1.5 分時）心搏数は 30 才台が最も低 く，これより年令が增しても減っても，心搏数の著明な 增加がみとめられだ。

しかし心搏数の回復率（完全回復を $100 \%$ とする）抒 よび $\mathrm{R} / \mathrm{E}$ 比は20才台を頂点として年令とともに機能が 不良となる関係がみられた。

4. oxygen-pulse は30才台がわずかに增大を示した が，年令変化は著明ではない。

5. 橋本の評点法炕より佮力指数 (IPC) を求めると 代謝関係の評点は20才台を最高之して 30 才以後に急速な 減少をみるが，循環系関係の評点は30才台を頂点とする 年令変化を示し，これより若年曆では代謝系評点よりも 低いが，高年屬では代謝系評点よりも高点をとることが 示された。 